\title{
IL31 wt Allele
}

National Cancer Institute

\section{Source}

National Cancer Institute. IL31 wt Allele. NCI Thesaurus. Code C113836.

Human IL31 wild-type allele is located in the vicinity of 12 q24.31 and is approximately 2 $\mathrm{kb}$ in length. This allele, which encodes interleukin-31 protein, plays a role in both signal transduction and immunity. 